DE DE GRUYTER OPEN

Journal of Intercultural Management

Vol. 7, No. 1, January 2015, pp. 75-95

DOI 10.1515/joim-2015-0005

\title{
Izabela Kołodziejczyk-Olczak*
}

University of Lodz

Anna Sołtys*

University of Social Sciences

\author{
Ali Rashidi* \\ Folkuniversitetet Uppsala, Sweden
}

Lynda Scott*

University of Strathclyde, Centre for Lifelong Learning, Scotland, Glasgow

\section{Is Management of Aging Human Resources Worthwhile? Evaluation of an Age Management Model}

\begin{abstract}
Societies are aging. This brings with it a lot of negative consequences and risks to companies. Employers are facing a phenomenon which is not fully recognized, and as a corollary there are no fully developed standards and tools for age management as an implemented strategy and personnel policy. Older workers have different needs and expectations regarding not only working conditions, ergonomics, safety, health care etc., but also with respect to social relationships, communication, career perspectives, professional training and development. These factors, as well as the results of research on aging, should be reflected in the practice of human resource management. The purpose of this article is to show the LIKE Age Management Model (LAMM) in the context of suggested practices and models to date. LAMM contains two types of functions: primary ones regarding recruitment, learning and development, health protection and promotion, exit and transitions to retirement procedures; and supporting ones related
\end{abstract}

\footnotetext{
asoltys@spoleczna.pl; asoltys@spoleczna.pl; ali.rashidi@ffolkuniversitetet.se; lynda.scott@strath.ac.uk
} 
with flexible working hours, career development, redeployment and comprehensive approaches. The model has been evaluated on the basis of diverse criteria in the context of the proposed instruments described in the LAMM with respect to functions and possibilities of implementation in enterprises.

Key words: Age Management, Age Management Model, Ageing, Human Resource Management, Evaluation

\section{Introduction}

The ageing of societies is an objective phenomenon of the social environment of organizations. Contemporary companies will soon face, or may already have to cope with, the problems of a labour shortage and knowledge drain - the result of the retirement of older employees. It is estimated in 2060 manpower will decrease in Europe from 307 million to 265 million, and in Poland from 25 million to 16 million. ${ }^{* *}$ During this same time the ageing population will increase 2.5 times.** In the Polish case it may be predicted that in each decade the number of working people will decrease by 2 million. This means that even as the general population in Europe will increase up to 517 million, compared with 502 million in 2010, the population will be much older $-30 \%$ of Europeans will be 65 years old or older. This means that the percentage of people aged 15-64 will decrease from 67\% down to $56 \%$. For each pensioner there will be two employees. On the other hand there are prognoses that the available number or workplaces will increase by 1.5 million in upcoming years. ${ }^{* * * *}$

The answer to these challenges lies in age management. There are many projects and a lot of ongoing interdisciplinary research on various aspects of age management. In order to help employers to better understand the concept of age management, the project LIKE (Learning through Innovative management concepts to ensure transfer of Knowledge of Elderly people) has been designed and evaluated. This project developed a model which contributed to an increase in the competitiveness of companies and improvement in their services, and at the same time facilitated the career development of older employees by helping them use their potential to the fullest.

The aim of this article is to present the results of the evaluation of the age management model in two organizations, against the background of theoretical considerations. In order to achieve our objective we used elements of the following methodologies: content analysis, case studies, analysis of the age structure, and group interviews. The structure of the article is focused on the presentation of

\footnotetext{
** http://appsso.eurostat.ec.europa.eu/nui/show.do?dataset=proj_10c2150p\&lang=en

*** http://appsso.eurostat.ec.europa.eu/nui/show.do?dataset=proj_10c2150p\&lang=en

**** http://www.mrjob.pl/aktualnosci/nawet-21-miliona-nowych-miejsc-pracy-mazagwarantowac-unijny-plan-inwestycyjny/
} 
age management terminology, dimensions of human resources ageing, and models of age management. One of the presented models which was the subject of our evaluation process is the LAMM. At the end of the article we present our general conclusions and recommendations for the practice.

\section{Age Management Terminology}

Further research and the implementation of projects, as well as the analysis of best practices, leads on one hand to the multiplication of theoretical and empirical achievements, and on the other hand to standardized terminology and a more uniform understanding of age. This implies the presence of the variety and number of approaches. According to one, "aging human resources will demand a different approach and new solutions for the model of human resources management, starting from planning procedures, recruitment, training and ending with the termination of employees. It requires changes in health policy and employment solutions to support aging workers due to their potential and effectiveness. However the most challenging change must appear in personnel policy, organizational culture, and employers' attitudes." [Soltys, 2014]. Another approach shows that age is a way of managing human resource management, taking into account the aging of those resources. It also includes a variety of approaches adapted to mature workers' activities related to the organization of work and employment, recruitment, training and knowledge management, software development, balancing work and private life, and creating sustainable jobs [Kołodziejczyk-Olczak, 2014]. The conclusion is that age management can be understood in various ways. According to Naegele and Walker, age management tools overcome age barriers and/or promote age diversity, helping us to create an environment where individual workers are able to fulfil their potential without finding themselves in an unfavourable situation because of their age [Naegele, Walker, 2006, p.3]. Age management can be related to different dimensions of human resources management in an organisation, with a clear focus on ageing [Walker, 1997] and, more generally, on the management of an ageing workforce through public policy or collective bargaining [Walker, 2005, p.685]. The latter perspective approaches age management in a relatively broad way.

It is also emphasized that the concept of age management was developed in order to describe the wealth of practices, interventions, and strategies designed for this purpose, as follows:

- Age management can be implemented at different levels - the individual, the company or the labour market;

- Age management requires a multidisciplinary approach drawing from demography, pedagogy and andragogy, health care, occupational health and safety, work projection, ergonomics, career planning and many other disciplines;

- Age management focuses on the entire professional career, not only on older workers [TAEN, 2007, p.5]. 
The study's authors understand age management as an integrated construct, corresponding to both economic and social needs.

\section{Dimensions of Human Resources Ageing}

Many contemporary organizations claim to have problems regarding staff competences and attitudes. The most important are lack of experience, lack of technical, formal, and professional skills and competences, lack of suitable candidates to work or lack of business knowledge $e^{* * * * *}$. These may be caused by changes in formal education systems and generational change in attitudes towards work and career. The solutions to these kind of global staff problems are the paths to ensure that employees have permanent trainings, career progress, changes in recruitment strategies and concentration on retention of employees in deficit occupations ${ }^{* * * * * *}$.

Attention is directed to the age diversity of human resources, fixed as a base for the personnel management process - organizations which start from planning, recruitment and development procedures may have a trump, as it helps them to prevent: $^{* * * * * * * *}$

- Decreasing effectiveness of work and professional potency of older workers;

- Decreasing effectiveness and motivation in other workers and a poor working atmosphere;

- Increasing labour costs thanks to internal trainings, inadequate recruitment and poor institutional memory;

- Increasing labour costs caused by absences, health benefits, contributions to the Labour Fund and the Guaranteed Employee Benefits Fund.

From the social and ethical perspective, the ageing of human resources may influence the processes of stereotyping, create negative discrimination, reduce the purchasing power of older consumers, and lead to social exclusion and a general reduction of social benefits. From the employer's perspective, the implementation of age management may have an influence on the employer's image and be a part of employer branding, as well as improve loyalty relations and in the end increase competiveness, in accordance with the R. Cialdini rule - similarity - in relations with clients [Cialdini, 1996].

The first step in implementing an age management model should be an analysis of the age structure in the organization, which should be combined with an analysis of the organizational goals in the long-term perspective. This should include the characteristics of the clients, cooperators, and other social and business partners, as well the analysis of the strengths, weaknesses, opportunities and, what's more - the

\footnotetext{
***** http://www.hrnews.pl/reports

****** http://www.hrnews.pl/reports/2011_Badanie_Niedobor_talentow.pdf

******* http://www.zysk50plus.pl/storage/fck/file/PUBLIKACJE/Zarzadzanie_wiekiem_ miniporadnik.pdf
} 
threats to an organization's development. L'Hoste, Grevedon propose [L'Hoste, Grevedon, in Czernecka, Woszczyk, 2013] the evaluation of evaluate age structure according to four ideal shapes: pyramid, mushroom, clepsydra, and oval.

Figure 1. Types of age pyramids in organizations
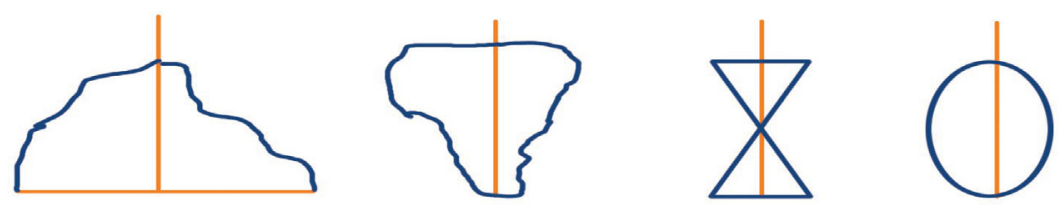

Source: L'Hoste, Grevedon, Papy-boom et compétitivité. Les nouveaux enjeux de l'entreprise, Édiotions Liaisons, Paris. [in:] Człowiek to inwestycja. Podrecznik do zarzadzania wiekiem, P. Woszczyk, M. Czernecka (ed.), Łódź 2013.

When we analyze the age structure, we have to answer some strategic questions regarding recruitment procedures as well development and motivation systems. There are also some questions which need to be answered:

1. Is there a greater fluctuation within younger or elderly workers?

2. Do the younger workers have enough professional knowledge and skills?

3. Is it easy to fluently replace retiring employees?

Each age structure requires different approaches for the strategic and personnel processes. If there is a predominance of employees in the age bracket $50+$, there is a necessity to determine:

1. Are they ready to work longer than the formal required age of retirement?

2. Is the motivation system effective enough to encourage them to work longer?

3. Is the organization in danger of losing its know-how?

4. Are there methods providing for the transfer the know-how and experience between employees?

In the situation when the employment of employees $50+$ dominates, it is also worth considering:

- In the case of permanent high growth, are there middle-aged employees and thus a large group of employees will be around the same age?

- How can organizations support ageing personnel, their health, and updated qualifications to ensure the same level of effectiveness and competiveness? 
From the perspective of social needs and the economic system, attention should be drawn to the fact that failure to implement age management or promote the employment of $50+$ workers has the following negative influences:

- it increases the social and economic costs of living, caused by poor engagement in the productive and consumption processes;

- it increases the cost social security and the health and welfare system caused by lack of contributions;

- there is a weaker integration of social responsibility;

- it increases the necessity to employ foreigners, which may cause identity problems, adaptive problems and possible social conflicts.

At the beginning of the new century many European organizations had to face up to the problem of human resources' aging. In some countries a systematic approach has been implemented in the form of financial support for companies employing workers over 50 or for employees willing to work longer than the possible retirement age. Most of the solutions have been created as a form of motivating employees aged $50+$ to work longer in situations of an increasing deficit of younger employees, lack of professional knowledge and qualifications caused by changing strategies of education and changes in the career perspective for the younger generation. The most popular practices include implementing flexible working hours, the possibility to receive salaries and pensions, lowering the cost of employment of 50+ workers, or providing better health care.

\section{The Age Management Models}

Within the aforementioned project LIKE, LAMM was developed. As a result of the adoption of this model and the implementation of the practices it contained, organizations have been able to increase the productivity of their older employees, sustain the competitiveness of a company, and what's more, to react to the demographic changes on a regular basis. It's worth mentioning the ways in which the concept of age management can be perceived. To begin with, the issue of age management, as the basis for increasing the possibilities for longer employment in an organisation, can be treated in either a broad or narrow fashion.

The model of age management developed for the purposes of the Project alludes to the "Value Chain" proposed by Porter, and juxtaposes it with the concepts of age management championed by Naegele and Walker [Desining..., 2013, p.14]. The model identifies Primary Functions which underpin good age management, using them as a starting point for any organization wishing to introduce age management policies. Specifically, these include: Recruitment and Retention; Learning and Development; Health Protection and Promotion; and Exit and Transition to Retirement.

In addition to the Primary Functions, Supporting Functions are also proposed, which reinforce good age management and complement the Primary ones. 
These include, e.g.: Flexible Working; Career Development; Redeployment; and Comprehensive Approaches. Figure 2 below presents the Age Management Value Chain.

Figure 2. Age Management Value Chain

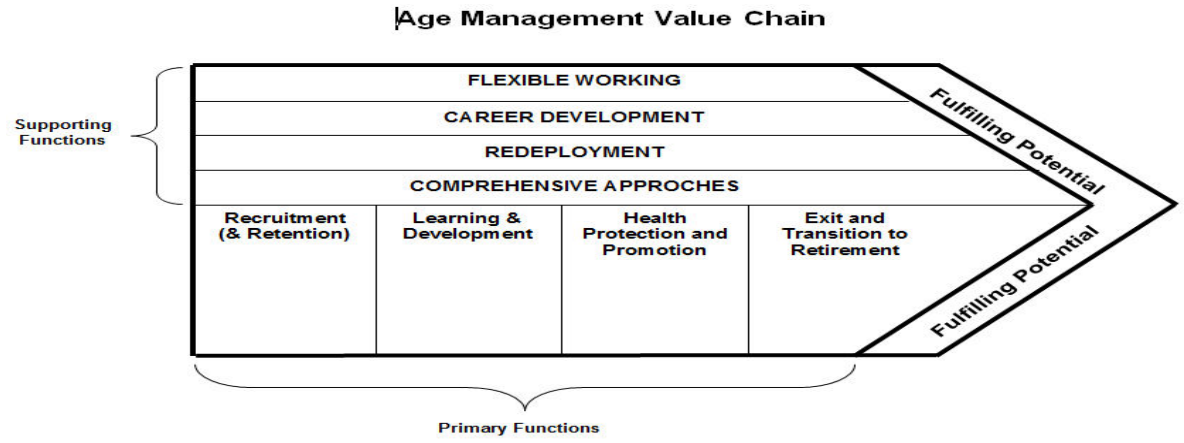

Adapted from Walker (2006)

Source: project materials, adapted from Naegele and Walker, 2006

Supporting Functions are used to implement the Primary Functions, while the superior aim is to fulfil the potential of workers at different ages. The main instruments and solutions supporting age management regarding Primary Functions are:

- recruitment and retention: an employment policy preferential for 50+ applicants, removal of the age criterion from job advertisements, elimination of intermediary discrimination from the recruitment and selection processes

- learning and development: training methods adjusted to the needs of 50+ employees as working with a supervisor, working in a team, self-education, professional development plans for workers aged over 50, knowledge and experience transfer from $50+$ employees to other workers, a mentoring system, a coaching system, an internal trainings system, work system in intergenerational teams

- health protection and promotion: regular analyses of the needs of 50+ employees concerning health, working time and responsibilities, analysis of workplaces and work tools in relation to the health needs of $50+$ employees, activities related to preventive health care for employees as meetings with specialists - e.g. nutritionists, the organization of lectures on health, nutrition and disease symptoms, contact with a specialized doctor, promotion of sports the organization of sports events, the provision of medical packages and health insurance for employees 
- Exit and transition to retirement: maintaining contact with retired employees, part-time work, participation in events organized by the company, sending best wishes on name days, birthdays or other special days, an opportunity to benefit from the Social Benefits Fund, individual contact of former superiors and coworkers with current employees, a request to participate in consultations and to share their experiences, a request to fill-in at work for absent employees during the holiday period or in the event of an insufficient number of personnel, talks related to retirement plans and employment time, cooperation with trade unions on age management

As regards Supporting Functions, the following tools and solutions may be implemented:

- Comprehensive approaches: a formal anti-discrimination policy, a regular analysis of the age structure, regular training courses for employees concerning equal opportunity policies, regular training courses for the managerial staff concerning an equal opportunity policy, appropriate review procedures available for the workers experiencing discrimination

- Career development: individual talks related to professional development

- Flexible working: professional development plans for workers aged 50+, which take into consideration the need for professional development, the need for the development of social skills, the need for advancement, the need for job position change, the need for a change in the scope of responsibilities - resignation from specific activities and tasks, the need for working time changes - a flexible working time schedule, activities aimed at adjusting the work place to the needs of $50+$ persons (connected with ergonomics, facilitating machine operation, a proper sitting posture, etc.), such as a change of furniture - desks, chairs, work tools, computers, lighting, and reorganization of the work place

- Redeployment: individual discussions related to the employment period.

The efficiency of the age management model depends on external and formal factors related to cooperation with the company, and on internal factors related to a specific company, its business activities and the solutions it has adopted so far.

There are both some similarities and some differences between LAMM and another age management models. A group of experts from Finnish Institute of Occupational Health defined the following eight general aspects of age management, which logically affect one another:

- Good knowledge about age structures

- Fair attitudes towards age

- Good management that understands individuality and diversity

- A good and operational age strategy

- Good work abilities, motivation, and the will to continue to work

- High level of competence 
- Good work organization and environment

- Good life [Ilmarinen, 2005, p.236], which can significantly influence the process of implementation of the age management model. This is why the extent to which a company is prepared to implement changes enabling pro-active age management should be taken into consideration.

Another model, also Ilmarinen's, is called the "Work Ability House Model" and describes the different dimensions affecting human ability. The author believes that ability is the right balance between work and individual resources e.g. preferences (values, attitudes and motivation), competences, health, and functional capacities. Besides the workplace, the family and close community also influence the balance. Aspects connected with society include: culture, legislation, education policy, social and health policy. The working environment is also important. The operational environment of organisations tends to change continuously due to globalisation, new technology, financial crises, etc. As a consequence, the work to be done in an organisation is subject to continuous development. Simultaneously, the organisation's human resources change, due for example to the ageing of the workforce (Ilmarinen, 2008).

The model developed by I. Kołodziejczyk-Olczak includes both employerfriendly practices and employee-friendly practices. At the centre of the model is a set of selected age management practices, which are distributed along a line dividing the multi-faceted benefits obtained by the employees and the organization's benefits. It is noteworthy that the key age management practices are equally beneficial for both parties, and include:

- management of competencies, including knowledge;

- motivation for work, commitment, well-being,

- training courses and development

- Work-Life Balance.

Practices more favourable to the employer include: diversity and generation management, flexibility, Employer Branding and monitoring the effects of the use of age management. Practices in which the greater beneficiary is employee are related to the health and healthcare (Kołodziejczyk-Olczak, 2014). It is important to note that organization strategy, its HR philosophy, organizational culture and its structure has significant effects on age management. Due to this fact, the process of evaluation of the age management model should be closely related to a company's strategy and its personnel policy so that all the key moments of implementation, their consequences, and the generated changes can be defined.

\section{Evaluation of LAMM - assumptions and results}

The general aim of our evaluation of LAMM was to indicate whether the proposed solutions could be implemented in organizational practice, and under 
which conditions. The model was evaluated in two Polish companies in 2014, selected based on their experience in dealing with the aging of human resources. It was a deliberate choice. The case analyses were used to present the specifics of the companies. The analysis of the age structure constituted the base for which to expose the depth of the aging problems and their impact on companies related to short-term and long-term activities and development. The specific instruments of LAMM were also the subject of evaluation in employee group interviews, based on an author's questionnaire.

For the purpose of the evaluation, the following criteria were adopted: timeliness, costs, the need for external help and support, current and future needs of the companies - examining individual approaches of both managers and workers.

Thus, in this preliminary stage the following questions had to be answered to form a foundation for the evaluation:

1. What companies could be interested in the model's implementation?

2. How should a company prepare for changes in the scope of human resources management?

3. What changes should be implemented within the scope of functioning policies, procedures and tools?

4. How should the staff be prepared for the changes?

5. What positive changes can be expected in the employment relations?

6 . What negative changes can appear in an organization?

7. How did the personal situations of the $50+$ workers change?

8. How did the company's situation regarding competitiveness and effectiveness change?

9. Which of the suggested activities are the most useful for employers?

The general conclusions and answers are presented in a SWOT analysis and in conclusions in the further part of this article. The second part of the evaluation was related to the question which of the instruments and tools of LAMM were beneficial both for the company and the workers, and, at the same time, did not generate losses, increase costs or decrease individual efficiency or the efficiency of the company. In the final considerations references to the European Commission criteria of the evaluation were taken into account.

\section{The Companies' characteristics}

The model evaluation process took place in two organizations from Lodz. Their characteristics are presented in Table 1. 
Table 1. Characteristics of the organization

\begin{tabular}{|l|l|}
\hline Organisation 1 & Organisation 2 \\
\hline This organization has been operating & This organisation was founded in 1973. It \\
since 1992. It has been offering a range & consists of 10 outpatient clinics which provide \\
of supporting services to companies and & services to 60,000 people from the Polesie \\
institutions all over Poland. The company has & district. \\
sufficient knowledge and experience, as well & The organisation owns several specialist clinics: \\
as the necessary potential to properly perform & surgery, orthopaedics, gynaecology, urology, \\
the services they offer. The organisation & laryngology, ophthalmology, rehabilitation, \\
specializes in: & dentistry, a laboratory and an imaging unit. It \\
Cleaning services & also runs 50 offices located in schools, which \\
Technical maintenance & provide nursing care for children. The health \\
Security services & care centre has its own sanitary transport \\
Temporary employment. & services. Doctors, nurses, and technicians have \\
This is a team of 6,700 people providing & the high skills and competences that are required \\
services in 4,500 different facilities all & for independent decision-making. The key values \\
over Poland, inside and outside buildings, & of the system are connected with the level of \\
with a total area of ca. $1,100,000$ sq.m. The & experience of the personnel and stability of \\
organisation hires 1,000 temporary employees & employment in all of the clinics. \\
who work in their partners' teams. It has the & \\
status of a Supported Employment Enterprise. & \\
\hline
\end{tabular}

Source: own compilation

In the first stage we examined the age structure of the employees of both companies. The results of these analyses are presented in Figure 3 below.

Figure 3

Pyramid of age (1st firm)
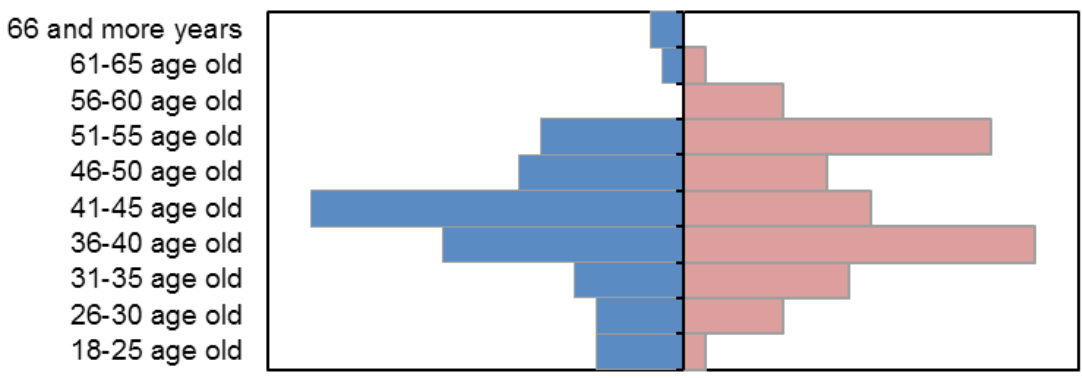


\section{Pyramid of age (2nd firm)}

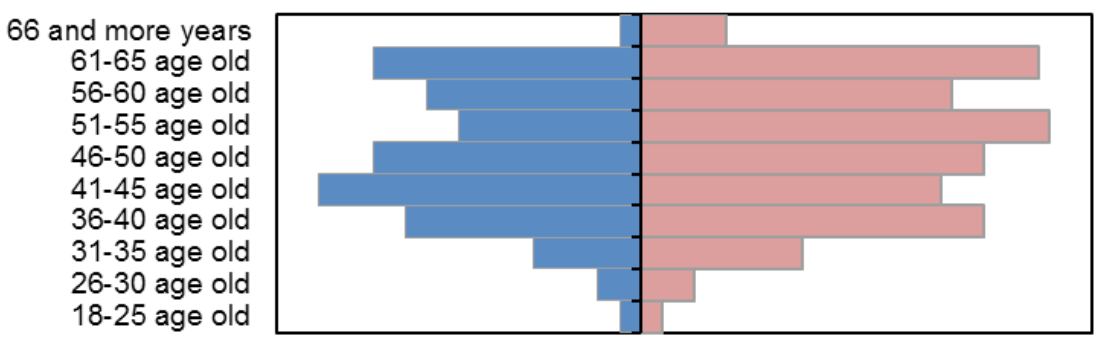

Source: own compilation

The structure of the second organization corresponds almost exactly to the "mushroom" type. This is a very disturbing result. In both organizations it is necessary to take steps towards the long-term rejuvenation of the staff.

\section{The LIKE Age Management Model Evaluation Results}

Assumptions of the LIKE project evaluation (all studies, interviews, workshops) showed risks and opportunities, and the strong and weak points of the concept, since it took into consideration not only the organizational perspective (costs, the possibility to adopt selected age management elements), but also the wider context (the high unemployment rate among young people, which could negatively influence the employers' attitude toward hiring older workers).

Research has shown that many of the instruments can be applied to an organization with only a small financial outlay. This refers mainly to the "soft" tools. They require conceptual work and implementation, but you can build on the experiences of employees, adjusted and supplemented by new knowledge specific to older workers.

Only the following areas require, in the opinion of the organizations, external support:

- Age discrimination (in the context of this problem: appropriate review procedures available for workers experiencing discrimination, contact with one's superior, contact with the person acting as an "intermediary", contact with an employment specialist, an internal help line, contact with an external specialist, contact with an attorney-at-law);

- Training methods adjusted to the needs of 50+ employees (achieved mainly by work with a supervisor, work in a team, self-education);

- Activities related to preventive health care for employees (meetings with specialists - e.g. nutritionists, organization of lectures on health, nutrition and disease symptoms, contact with a specialized doctor, promotion of sports - the organization of sporting events). 
Respondents were surprised by the multitude of possibilities of change, provided that their necessity was realized by the company. The conducted research allowed for the creation of a SWOT analysis, presented below.

Table 2. SWOT analysis of the age management concept

\begin{tabular}{|c|c|}
\hline STRONG POINTS & WEAK POINTS \\
\hline $\begin{array}{l}\text { - most of the tools can be implemented quickly, } \\
\text { without great expenditure } \\
\text { - an activity once started can be continued on a } \\
\text { regular basis } \\
\text { - it can be an element of the incentive scheme } \\
\text { for employees } \\
\text { - it can be used for brand building } \\
\text { - it is possible to implement only selected } \\
\text { elements of the model } \\
\text { - it covers all the areas of age management (sub- } \\
\text { functions) }\end{array}$ & $\begin{array}{l}\text { - some of the activities can only be introduced } \\
\text { with external help } \\
\text { - the development and implementation of other } \\
\text { AM practices require greater expenditures } \\
\text { - most of the solutions require an ongoing } \\
\text { structural approach, which entails changes in } \\
\text { the personnel policy and tools } \\
\text { - trained managerial staff who would be aware } \\
\text { of the problem is required }\end{array}$ \\
\hline OPPORTUNITIES & RISKS \\
\hline $\begin{array}{l}\text { - the growing awareness of employees' rights } \\
\text { and needs in organizations (especially in } \\
\text { Europe and well-developed countries) } \\
\text { - employees signalling their needs } \\
\text { - an opportunity for the employer to enhance } \\
\text { their good name } \\
\text { the managerial staff not only learns to } \\
\text { understand the problem - of ageing, but also } \\
\text { develops a general pro-employee attitude } \\
\text { the promotion of the model, and a gradual } \\
\text { development of age awareness among all } \\
\text { interested parties }\end{array}$ & $\begin{array}{l}\text { - the high level of unemployment among young } \\
\text { people } \\
\text { - the lack of a structural approach in the } \\
\text { employment policy } \\
\text { the company and its employees need a special } \\
\text { work environment, which makes it impossible } \\
\text { to implement some of the solutions } \\
\text { - the model includes some sub-functions whose } \\
\text { implementation entails significant expenditures }\end{array}$ \\
\hline
\end{tabular}

Source: own elaboration

Taking into consideration all the activities and evaluation areas, one can put forward the following conclusions:

- Compatibility with expectations - the presented model covered many of the employment-related needs mentioned by workers aged $50+$ in group interviews.

- Taking into account the number of problems - from the point of view of workers aged $50+$ - the presented LAMM was very comprehensive. It covered employment, development, health and social needs; nevertheless, it did not take into consideration cultural standards and values, which constituted the source of problems, or possible solutions related to stereotypes, employment relations, and the employer's responsibility.

- Increase/decrease in costs - the potential implementation of the age management 
model did not entail great expenditures, but it required many organizational changes, which included expanding the duties of the managerial staff and HR officers - they were made responsible for talks with the older workers concerning further employment, planning retirement, planning professional development, and changes in the scope of responsibilities. The costs were mostly related to the adjustment of the work place and the scope of duties to the needs of employees aged $50+$, to the support of external entities in the area of training, to additional benefits, and to activities promoting health.

- Implementation time - While the implementation of the model did not take long, nevertheless it was based on a regular, continuous implementation of certain solutions - regular assessment procedures of skills and needs, development plans, in-service training, and health promotion.

- Legal outcomes and consequences - all solutions suggested in the model were in accordance with the labour law in effect.

- Financial outcomes and consequences - the implementation of the model did not bring any direct financial benefits; they could be achieved only if older, experienced employees would decide to continue their work for the company. In an indirect way however, the model ought to lower the costs of sick leaves and eliminate the need to hire new, inexperienced workers. The direct expenditures were related to the adaptation of work places and work tools for $50+$ employees.

- Social outcomes and consequences - the solutions suggested in the model focused on improving the relations between employees and employers, as well as between employees themselves, and on introducing an atmosphere of mutual acceptance, understanding, and (indirectly) loyalty; in the long-term perspective, they could enhance the good name of the company.

- The number of implemented changes and their scope - the model not only suggested and assessed many solutions, with the advantage that they could be used in a comprehensive and structured way, but it also responded to the individual needs of both employees and employers.

- The majority of solutions presented in LAMM will have a significant influence on the improvement of employees' satisfaction and qualifications. However, one needs to keep in mind that the implementation of the proposed strategic solutions will only bring results in the long run. These results cannot be observed immediately [Sołtys, Kołodziejczyk-Olczak, 2014].

As a result of presentation of the LAMM to both companies and the assessment of the solutions that were introduced, the representatives of the companies decided to take certain steps which would allow for a more deliberate age management. The distribution of their preferences is presented below.

First of all, it has to be pointed out that evaluation is a necessary stage of management. Each planned and subsequently implemented activity requires feedback from the most important beneficiaries. 
The evaluation of LAMM attempted to answer the following questions:

- What kinds of companies could be interested in the model's implementation? It seems that in this case, when the proposed model is so comprehensive and covers almost all aspects of HR policy, it can be implemented not only in organisations in which most employees are over 50 years old, but in any company.

- How a should company be prepared for the changes in the area of human resources management? Undoubtedly, the implementation of the model requires a comprehensive and systematic approach to the activities related to health promotion, the planning of employment and retirements, and the planning of career development. Such activities can be conducted by properly trained specialists from the HR department or the managerial staff prepared to perform HR tasks. The implementation of the model may also require improvement of a company's flexibility in terms of work organisation, distribution of tasks and responsibilities and the adaptation of the workplace.

- What changes should be implemented in terms of present policies, procedures and tools? If a company has not implemented a comprehensive HR policy yet, then changes in the decision-making and HR areas definitely need to be implemented, These include, e.g., regular interviews concerning their employees' careers, competence management, and the adjustment of training methods to age requirements.

- How should the staff be prepared for the changes? Most of all, the company needs to implement a formal non-discrimination policy and to instruct its employees about their rights and the company's activities aimed at the needs of $50+$ employees. It is also recommended that the employees are prepared to use certain procedures.

- What positive changes can be expected in the employment relations? Increased awareness, enhancement of the good name of the employer, conscious responsibility towards employees, respect for a team of employees who are diverse in terms of age, and increased loyalty and motivation of the employees.

- What negative changes can appear in an organisation? Organisational changes aimed at the improvement of working conditions and the implementation of systemic solutions in HR policy will not entail any negative changes, such as large expenditure or organisational changes. Most solutions of the age management model can be implemented as part of the tasks of HR department specialists or by properly trained managerial staff responsible for the HR policy.

- How has the personal situation of 50+ workers' changed? One can observe an increased sense of being needed, a possibility of sharing knowledge within a mentoring system, increased motivation to work, the possibility of balancing private life with career, and improved health protection. 
- How has the company's situation regarding competitiveness and effectiveness changed? The evaluation does not offer any direct answer to this question, as no research into this issue was conducted. However, it is assumed that changes in the position and responsibilities of $50+$ employees do not exclude the possibility of assigning these responsibilities to other employees in places where work systems oriented towards quantitative results are used.

- Which of the suggested activities are most useful for employees? Here one may point out health protection, the possibility of modifying the scope of responsibilities, flexible working hours, striking a proper balance between private life and career, the possibility of professional development [Sołtys, Kołodziejczyk-Olczak, 2014].

Attention was focused on the fact that the concept is divided into several modules under which various tools are proposed. These solutions are a part of a personnel policy that emphasizes an individual approach towards workers and their needs, depending on their individual situation with respect to age, health and family. The main emphasis is placed on making the forms of employment and work organisation more flexible and on changing the attitudes towards personnel-related decisions.

While demonstrating the model, it was emphasised that the solutions presented in the model had been functioning in the companies for many years and they were an answer to the changing expectations of workers, which in times of a shortage of qualified staff, is the only rational approach towards employment. This means that in practice employers and managing staff can use verified activities and decision patterns and they do not necessarily need to implement all the solutions described in the previous project activities. What is important for employers is the fact that they can choose certain tools and suggestions and adapt them to their own specific needs.

In order to properly evaluate the proposed model, it is recommended that further research be conducted based on the solutions implemented and monitored on the basis of selected indicators, and that a two-stage evaluation is carried out. Such an evaluation would allow to assess the input, effects and the implementation method from the perspective of selected criteria which, pursuant to the recommendations of the European Commission, include: relevance, effectiveness, efficiency, impact and sustainability. 
Figure 4. Fulfilment of selected criteria by the LIKE model

\begin{tabular}{|c|c|c|}
\hline Criterion & Description & $\begin{array}{l}\text { Criteria fulfilment by the LIKE } \\
\text { model }\end{array}$ \\
\hline $\begin{array}{l}\text { Relevance } \\
\text { (objectives vs } \\
\text { needs) }\end{array}$ & $\begin{array}{l}\text { This dimension concerns the structure } \\
\text { of the model itself, its objectives and } \\
\text { the possibility of their fulfilment via } \\
\text { the conducted activities. It allows } \\
\text { to assess the extent to which the } \\
\text { objectives are consistent with the } \\
\text { beneficiaries' requirements and } \\
\text { whether the objectives correspond to } \\
\text { the initial assumptions. }\end{array}$ & $\begin{array}{l}\text { The model's structure and the selection } \\
\text { of primary and supporting functions are } \\
\text { correct. }\end{array}$ \\
\hline $\begin{array}{l}\text { Effectiveness } \\
\text { (plan vs } \\
\text { performance) }\end{array}$ & $\begin{array}{l}\text { The effectiveness criterion allows us } \\
\text { to assess the extent to which the set of } \\
\text { objectives were achieved. It requires } \\
\text { the preparation of a summary of the } \\
\text { model's forecast and actual results. In } \\
\text { the case of an analysis of the model's } \\
\text { effectiveness, it is recommended that } \\
\text { the connections between the structure } \\
\text { of activities and their successes and } \\
\text { failures - related to the planned } \\
\text { effects - are indicated, i.e. expressed by } \\
\text { indicators. }\end{array}$ & $\begin{array}{l}\text { The objectives related to the pilot } \\
\text { implementation have been achieved. } \\
\text { The goal was a survey of attitudes and } \\
\text { of the need for the implementation of } \\
\text { age management solutions in accordance } \\
\text { with the LIKE model in two companies. }\end{array}$ \\
\hline $\begin{array}{l}\text { Efficiency } \\
\text { (input vs } \\
\text { effects) }\end{array}$ & $\begin{array}{l}\text { This involves an assessment of the } \\
\text { ratio of effects to input and the } \\
\text { determination of the effectiveness } \\
\text { of the inputs in terms of results. } \\
\text { It includes an analysis of how } \\
\text { economically the inputs translated } \\
\text { into individual results and the impact } \\
\text { of the model on the company. In the } \\
\text { context of the pilot implementation, } \\
\text { the main task of the efficiency criterion } \\
\text { is to assess the estimated costs of the } \\
\text { broader implementation of the model. }\end{array}$ & $\begin{array}{l}\text { In the case of internally financed } \\
\text { projects (the EU resources in this } \\
\text { particular case), it is very difficult to } \\
\text { determine the efficiency of the pilot } \\
\text { study. The piloting has proved that, } \\
\text { according to employers, certain age } \\
\text { management functions (for example, } \\
\text { those related to ergonomics) require } \\
\text { high expenditures. The project uses a } \\
\text { low-cost approach, and the previously- } \\
\text { described test solutions required an } \\
\text { input of time and attention rather than a } \\
\text { financial input. }\end{array}$ \\
\hline
\end{tabular}




\begin{tabular}{|l|l|l|}
\hline $\begin{array}{l}\text { Impact } \\
\text { (effects vs } \\
\text { needs) }\end{array}$ & $\begin{array}{l}\text { This is the most important evaluation } \\
\text { criterion of the model. This dimension } \\
\text { focuses on the beneficiaries and their } \\
\text { needs. The evaluator should determine } \\
\text { to what extent the model responds to } \\
\text { the target group's needs and solves } \\
\text { the identified problems. The evaluator } \\
\text { examines all consequences and the } \\
\text { extent to which the product (model) } \\
\text { has managed to solve the problems. }\end{array}$ & $\begin{array}{l}\text { The evaluation has proved that the } \\
\text { model responds to the target group's } \\
\text { of employers hiring mature and 50+ } \\
\text { people. }\end{array}$ \\
\hline $\begin{array}{l}\text { Sustainability } \\
\text { (the project's } \\
\text { impact } \\
\text { after its } \\
\text { completion) }\end{array}$ & $\begin{array}{l}\text { When public funds are used, } \\
\text { sustainability is a very desirable } \\
\text { element of the achieved effects. } \\
\text { Sustainability should be assessed in } \\
\text { the context of all the objectives and } \\
\text { positive effects to beneficiaries and } \\
\text { institutions which the programme was } \\
\text { supposed to achieve. }\end{array}$ & $\begin{array}{l}\text { The model developed within the } \\
\text { project is sustainable. The relationships } \\
\text { it presents can be developed in an } \\
\text { operational or instrumental form. The } \\
\text { model constitutes a good basis. } \\
\text { The LIKE model's evaluation showed } \\
\text { the beneficiaries how significant the } \\
\text { problem of ageing human resources is to } \\
\text { an organisation and offered them a tool } \\
\text { which helped them to prevent negative } \\
\text { effects and to seize opportunities. } \\
\text { The model is a sustainable resource for } \\
\text { other groups: consultancy and training } \\
\text { institutions, academics and students. }\end{array}$ \\
\hline
\end{tabular}

Source: Own conclusions

The adopted practices can stimulate an increase of efficiency, competitiveness and employability, which was noted in the course of the pilot study. Participants underscored that their employers supported them in the development of those competences that were needed to perform their professional responsibilities. They had very few opportunities to change their job positions or scope of responsibilities. While the model covers this issue, such solutions were very rarely used in practice in the pilot companies. They adopted many solutions that were uncommon in other companies and were conscious of their shortcomings in the area of age management.

\section{Conclusions}

As we mentioned at the outset, human resources are ageing. That aspect cannot be ignored and globally organizations must face up to it by taking proper account of the varying demographic and social parameters of the populations affected [Mahon, Millar, 2014, p.564]. The analysis of the age management model has led to the conclusion that, as regards the problem of ageing human resources, a systematic and comprehensive approach is needed above all. The tools and solutions suggested in LAMM are usually not expensive, but they require changes in the personnel policy 
and vision, implemented by specialized divisions or directly by the managerial staff. Hence the most important part of the concept is becoming aware of the various opportunities related to the implementation of the whole model, or only chosen elements. Our evaluation process led to the conclusion that the employees believed that most of the solutions were very attractive and not only to workers aged 50+, but also to other workers, despite the fact that both of the companies had a very employee-friendly attitude, good team atmosphere, and an individual approach to their workers and their needs. Other studies have shown that age management actions are make for a better and healthier workplace. Workplaces can support good health and promote healthy lifestyles, and healthy workers are more efficient and more productive, so adopting a holistic approach to health, mental health and well-being should be a management issue [Ahonen, 2012, p.3].

LAMM is a response to the needs and expectations of both main stakeholders - employers and employees. It is an efficient and an integrating approach with many dimensions, but the process of implementation is very important. The model can be recommended as a practical tool for strengthening the personnel policy of organisations.

We identify additional avenues for future research by drawing on data from other organizations, other sectors, markets or countries.

\section{Literature}

Ahtonen, A. (2012). Healthy and active ageing: turning the 'silver' economy into gold. EPC, March.

Cialdini, R. (1996). Wywieranie wplywu na ludzi. Teoria i praktyka. Gdańsk: GWP.

Designing Model for Enterprises on Age Management, (2013) LIKE.

Ilmarinen, J. (2005). Towards a Longer Worklife! Ageing and the Quality of Worklife in the European Union. Helsinki: Finnish Institute of Occupational Health, Ministry of Social Affairs and Health.

Ilmarinen, J.(2008). Promoting active ageing in the workplace. European Agency for Safety and Health at Work, http://osha.europa.eu (czerwiec 2015).

L'Hoste, Grevedon (2013). Papy-boom et compétitivité. Les nowveaux enjeux de l'entreprise. Paris: Édiotions Liaisons. In: Cžtowiek to inwestycja. Podrecznik do zarzadzania wiekiem. Woszczyk, P., Czernecka, M. (ed.), Łódź.

Kołodziejczyk-Olczak, I. (2014). Zarzadzanie pracownikami w dojrzalym wieku. Wyzwania i problemy. Łódź: Wydawnictwo Uniwersytetu Łódzkiego.

Kryńska, E. (ed.) (2013). Elastyczne formy zatrudnienia i organizacji pracy a aktywnosí́ zawodowa osób stars zych, Warszawa: IPiSS.

Kryńska, E., Szukalski, P. (eds.) (2013). Rozwiqzania sprzyjajace aktymnemu starzeniu sie w wybranych krajach Unii Europejskiej, Raport końcony. Łódź: Wydawnictwo UŁ.

Mahon, J. F., Millar, C.J.M., (2014). ManAGEment: the challenges of global age diversity for corporations and governments. Journal of Organizational Change Management, Vol. 27 Iss 4. 
Naegele, G, Walker, A. (2006). A guide to good practice in age management. Office for Official Publications of the European Communities.

Sołtys, A. (2014). Zarządzanie wiekiem jako nowy priorytet polityki personalnej. In: Przedsiębiorczośc i Zarzqdzanie, t. XIV(9), Sokołowski J. (ed.) Sołtys A., Kolodziejczyk-Olczak I. (2014), Evaluation of the age management concept. Lódź: SAN, , http://like.lllprojects. eu/index.php/pl/

Walker, A. (1997). Combating Age Barriers in Employment - A European Research Report. European Foundation Dublin.

Walker, A. (2005). The Emergence of Age Management in Europe. International Journal of Organizational Behavior, Volume 10 (1).

\section{Electronic Bibliography:}

Adecco Group White Paper, It's time to manage age. Overview of labour market practices affecting older workers in Europe, http://www.adecco.com/en-US/Industry-Insights/ Pages/Issues.aspx

http://www.age-work-balance.metropolisnet.eu/ [20 Dec 2014].

http://aslect.eu/index.php/en/results/publication [20 Mar 2015].

http://blog.refa.pl/zarzadzanie-wiekiem-w-przedsiebiorstwie/ [20 Mar 2015].

http://www.cedefop.europa.eu/EN/Files/9077_en.pdf [20 Mar 2015].

Chris Ball, TAEN - The Age and Employment Network Defining Age Management: Information and Discussion Paper, 2007 http://taen.org.uk/uploads/resources/Defining Age_Management.pdf

http://ec.europa.eu/news/economy/120515_pl.htm [20 Dec 2014].

http://ec.europa.eu/social/main.jsp?langId=en\&catId=89\&newsId=1837\&furtherNews= yes [20 Jan 2015].

http://www.eurofound.europa.eu/pubdocs/2012/66/en/1/EF1266EN.pdf [20 Mar 2015]. http://kadry.nf.pl/Artykul/10877/Jak-wlasciwie-zarzadzac-wiekiem-w-przedsiebiorstwie/ komunikacja-lifelong-learning-stres-zarzadzanie-wiekiem/ [20 Dec 2014].

http://www.hrnews.pl/reports [12 Jan 2015].

http://www.hrnews.pl/reports/2011_Badanie_Niedobor_talentow.pdf [12 Jan 2015].

http://like.lllprojects.eu/index.php/pl/ [20 Jan 2015].

L. Nowaczyk http://kadry.nf.pl/Artykul/10877/Str_2/Jak-wlasciwie-zarzadzac-wiekiemw-przedsiebiorstwie/komunikacja-lifelong-learning-stres-zarzadzanie-wiekiem/

http://www.parp.gov.pl/files/74/75/76/487/494/9417.pdf [20 Jan 2015].

Promowanie zdrowia i działań prozdrowotnych w miejscu pracy - informacje dla pracodawców, Facts 90, Europejska Agencja Bezpieczeństwa i Zdrowia w Pracy, http://osha. europa.eu

http://trendfuture.wordpress.com/2012/02/21/kim-jest-pokolenie-z/ [12 Jan 2015]. 
S. Toney, C. Meyer, M. Semmler, X. Pitoiset, Long-Term Ageing Management Strategies for Nuclear Power Plants http://www-pub.iaea.org/MTCD/publications/PDF/P1500_ CD_Web/htm/pdf/topic4/4S05_X.\%20Pitoiset.pdf [12 Jan 2015].

http://www.zysk50plus.pl/storage/fck/file/PUBLIKACJE/Zarzadzanie_wiekiem_miniporadnik.pdf [14 Jan 2015].

http://wyborcza.pl/0,132486.html [13 Jan 2015].

http://appsso.eurostat.ec.europa.eu/nui/show.do?dataset=proj_10c2150p\&lang=en Jan 2015].

http://appsso.eurostat.ec.europa.eu/nui/show.do?dataset=proj_10c2150p\&lang=en Jan 2015].

http://www.mrjob.pl/aktualnosci/nawet-21-miliona-nowych-miejsc-pracy-ma-zagwarantowac-unijny-plan-inwestycyjny/[13 Jan 2015]. 